\section{Classified Advertising}

Classified advertising orders and copy, and cancellations, should be addressed to the Publications Office, ACRL, 50 East Huron Street, Chicago 60611, and should reach that office before the tenth of the month preceding publication of issue desired. Copy received after that time may be held for the next issue.

Rate for classified advertising is $\$ 1.25$ per printed line. No additional charge is made for nonmember advertising.

\section{FOR SALE}

FINE \& APPLIED ARTS REFERENCE COLLECTION. ca 500 titles. Checklist and particulars sent to institutions upon application. C. Verbeke, North Salem, N.H. 03073. Tel. (603) 893-0601.

BACK ISSUES-Unbound original editions, clean, top condition. Over $20 \%$ below list, shipping extra. W. Parrish, 309 Woodbine Rd., Stamford, Conn. 06903. Review Scient. Instrum. V 16-33 (1945-62) \$260; Acta Crystallographica V 1-23 (1948-67) \$570; Mineralogical Abstracts V 14-18 (1959-67) \$130; Bull. Soc. franc. Min. Crist. V 82-90 (1959-67) $\$ 90$; Amer. Mineralogist V 2-4, 20-52 (191719 , 1935-67) plus 3 indices, $\$ 575$. $\$ 1500$ for entire lot--more than $25 \%$ below list.
POSITIONS WANTED

ADMINISTRATOR MLS, male, 39 years old, 11 years experience. At present Associate Director for Technical Processes in a large university library. Seeks directorship of college or university library, or associate directorship in a university library. No geographical preference. Box 746, CRL, 50 E. Huron St., Chicago 60611 .

\section{POSITIONS OPEN}

Acquisitions

ACQUISITIONS LIBRARIAN who will also provide some reader service for an old established liberal arts college now located on a new campus. This is a new position in a new library building. A chance for a young person to learn and grow professionally with a fastgrowing library. Faculty status, T.I.A.A., C.R.E.F., major medical, one month vacation and other liberal group benefits. M.L.S. required. Salary $\$ 7,000-\$ 8,000$. Apply: James T. Michna, Library Director, Howard Colman Library, Rockford College, Rockford, Illinois 61101.

Administration

LIBRARY DIRECTOR: Challenging opportunity to help plan, build and administer the new Central Reference Library in Nassau County, New York (population approximately

\title{
7th Collective Index to Chemical Abstracts 1962-1966
}

\section{Your guide to nearly}

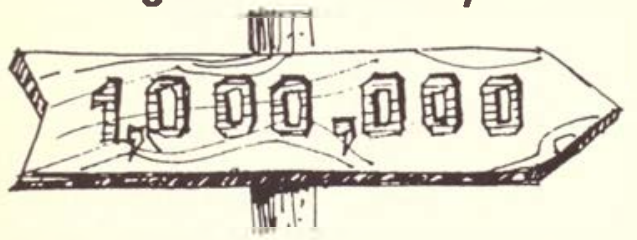

chemical papers

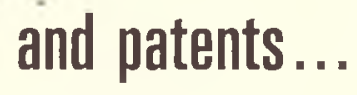

The 7TH COLLECTIVE INDEX gives you access to one-fourth of all abstracts ever published in CHEMICAL ABSTRACTS. Volumes 56-65 of CHEMICAL ABSTRACTS are included. The 10 separate Subject Indexes, Formula Indexes, Author Indexes and Patent Indexes for these volumes are combined, re-edited, and updated into one Subject Index, one Formula Index, one Author Index and one Numerical Patent Index and Patent Concordance. You can focus on your interests within this large body of information and see 5 years of development in your specialty.
Publication of the 7TH COLLECTIVE INDEX began in April, 1967. Subscription rates for the complete 28 volume set are as follows:

\section{ACS Members* ${ }^{*} . . . \$ 2,000$}

Colleges \& Universities* . \$2,000

All Others . . . . . . . . \$2,500

Postage: Foreign-\$24.00: PUAS \& Canada$\$ 16.00$

*Due to the special rate granted, purchase is made through a lease agreement.

\section{*}

Order from:

\section{American Chemical Society} 1155 Sixteenth St. N. W. / Washington, D.C. 20036

$$
\text { * }
$$

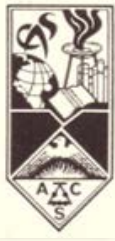

CHEMICAL ABSTRACTS SERVICE

American Chemical Society

Columbus. Ohio 43216 
$1,500,000)$. Send resume attention Dr. Sally B. Ronsheim, John F. Kennedy Educational, Civic and Cultural Center, Firehouse, Building 20, Mitchel Field, Garden City, New York 11530.

HEAD LIBRARIAN, Wisconsin State University, Superior, Wisconsin 54880. Multi-purpose University with 3300 enrollment. New library building, September 1968. Collection of 130,000 volumes, with professional staff of seven. Candidate with Ph.D. or M.L.S. with additional graduate work and experience preferred. Annual appointment with salary open and competitive, depending on training and experience, effective July 1, 1969. Contact Dr. John C. Haugland, Vice President for Academic Affairs, Wisconsin State University, Superior, Wisconsin 54880 .

\section{Automation}

EITHER: Library Automation systems specialist or Cataloger to begin work immediately at Millersville State College, Lancaster, Pennsylvania. $\$ 6,910.00$ to $\$ 13,680.00$ for 9 months. Summer work optional. State supported; present staff of 17 professionals, new building with dial access system in operation. Contact: Mr. John S. Maine, Library Director, Millersville State College, Millersville, Pa. 17551.

Cataloging

CATALOG LIBRARIAN wanted for small liberal arts college. M.L.S. from an accredited A.L.A. library school. Experience preferred but not mandatory. Will consider applicants with B.A.L.S., B.S.L.S. Beginning salary dependent on qualifications and experience. Send resumes to: Miss Carolvn Eaves, Librarian, Howard Payne College, Brownwood, Texas 76801.

CATALOGER，\$9000 a year. University Library in midwest. One month vacation, retirement, health insurance, congenial community and staff. Some relevant cataloging experience is desired, but adaptability to change is essential. If interested, please write Box 740 , CRL, 50 E. Huron St., Chicago 60611.

CATALOGING POSITIONS, \$7600. And up, depending on qualifications, for materials in (1) near eastern languages; (2) Spanish and Portuguese. Good fringe benefits on campus with 28,000 students. Apply to Miss Jane Flener, Asst. Director, Indiana University, Library, Bloomington, IN 47401.

HEAD CAT. LIB.-You bring: 3-5 year exp., pref. with LC System, cat. in acad. or pub. lib.; 5th yr. LS degr. from accred. lib. sch.; reading knowledge at least one mod. lang.; supervisory ability. We offer: $\$ 8,700-\$ 9,200$ (with large increase within 2 yrs.); good chance for early advancement; Asst. Prof. rank and privileges; unparalleled fringe benefits, good working and living conditions (new lib. planned for completion within 4 yrs.). Young staff, good morale, plenty of creative work. Send resumé (ed. and prof.), 3 refs. (at least 1 libn.), lib. sch. dossier. WRITE OR PHONE (COLLECT): E. OBOLER, IDAHO STATE UNIVERSITY LIBRARY, POCATELLO, IDAHO $83201,208-236-3480$.

CATALOG LIBRARIAN. Opening after January I, 1969. Graduate degree in Library Science. Additional graduate degree in subject area desirable. Knowledge of French or Spanish. Faculty status. Salary for nine months $\$ 6,910-\$ 8,400$ and up depending on qualifications. Optional nine weeks in summer on same salary scale as above. Library of 175,000 volumes. New building 1968. Apply to Miss Alma Winton, Head Librarian, Shippensburg State College, Shippensburg, Pa. 17257.

\section{Multiple}

ACADEMIC AND RESEARCH LIBRARIANS. Opportunity for professional librarians with three to five years of appropriate experience to aid in the development of cooperative programs among college, university, public and research libraries in the New York State 3R's Program. Assistants in Academic and Research Libraries-Salary Range: \$11,365-\$13,675, Challenging Duties-(1) Consultant service to 3R's Systems; (2) Advisory assistance to academic, special and research libraries; (3) Assistant planning projects to foster interlibrary cooperation. Associates in Academic and Research Libraries-Salary Range: \$14,070-\$16,780. Challenging Duties-(1) Plan and supervise projects relating to interlibrary cooperation among college, special and public libraries; (2) Supervision of staff of a field services section; (3) Consultant services to academic and research libraries. Excellent Fringe Benefits. Inquiries and resumes should be sent to: Division of Personnel, New York State Education Department, Albany, New York 12224.

(1) ASSISTANT ACQUISITIONS LIBRARIAN responsible for supervision of bibliographic searching, coordination of book selection; other possible responsibilities: development of documents collection. (2) CATALOGER to assist in reclassification from Dewey to L.C.; also some responsibility for current material. Minimum academic requirement for both positions: Master's degree in Library Science from ALA accredited school. Full faculty status. Salary open. Apply to: Fritz Veit, Director of Libraries, Chicago State College, 6800 S. Stewart Ave., Chicago, Ill. 60621.

BEAUTIFUL SOUTHWESTERN LOUISIANA-a floral paradise and fisherman's delight. Seafood and French cuisine combine for the best eating in the South. To share these unmatchables in the midst of French Acadiana, we need: I. Head of Readers Services to supervise and coordinate the Divisions of Humanities, Science and Social Sciences, Circulation, Reserve Books, Audio Department, News- 
papers and Microforms, Documents and the Louisiana Collection. II. Head of Technical Services to coordinate Acquisitions, Cataloging and Circulation, to apply the new technology and to initiate procedures for automation. Positions I and II defined as Associate or Assistant Director, depending on experience and qualifications. Salary for both negotiable, range $\$ 12,000-\$ 14,000$. III. Assistant Acquisitions Librarian, to supervise 5 clerical assistants, to coordinate bibliographic control and to help analyze procedures prior to automation. Minimum qualifications: M.A.L.S. Salary negotiable depending on experience, minimum $\$ 8,000$. IV. Systems specialist to study procedures of entire library, to assist in statistical analysis and to work with programmers. Minimum qualifications: appropriate degrees, experience. Salary negotiable, depending on experience, minimum $\$ 12,000$. V. Any combination of above. We may be able to combine or re-define these positions around your experience or preference. Faculty rank and usual benefits, Apply: William E. McGrath, Director of Libraries, University of Southwestern Louisiana, Lafayette, La. 70501.

STOUT STATE UNIVERSITY, Menomonie, Wisconsin, is seeking candidates for three positions: Acting Catalog Librarian (September 1969-August 1971), Assistant Catalog Librarian, and Educational Materials Center Librarian. For the first, a cataloger with considerable experience is desired, to direct the work of the department while the regular department head is on leave. All new cataloging is in L.C.; conversion from Dewey is in process. Familiarity with MARC, and an interest in continuing and developing automation in progress, are essential. For the Assistant Catalog Librarian, a minimum of two years' cataloging experience is desired, but not required. The position of Educational Materials Center Librarian carries the responsibility and challenge of initiating and developing a new department. Background in this area is desired. Positions carry faculty status and perquisites, including excellent fringe benefits. Salaries are on academic year basis, with additional compensation for summer session employment, which is customary. For Acting Catalog Librarian and Educational Materials Center Librarian: Salary open and appropriate to training and experience. For Assistant Catalog Librarian, $\$ 8,200$ and up with requisite training and some experience. Master's degree in Library Science required. Stout is a Wisconsin State University, specializing in industrial education, industrial technology. home economics, vocational education, and related fields. Present enrollment is 4,330. An air-conditioned addition to the present building (readv in the summer of 1969) will provide excellent working facilities. Menomonie is a small city, situated in the heart of beautiful country, with easy freeway access to Minneapolis-St. Paul, 70 miles to the West. Apply to: Miss Phyllis D. Bentley, Librarian, The Robert L. Pierce Library, Stout State University, Mennmonie, Wisconsin 54751 .
Public Services

PUBLIC SERVICE LIBRARIAN-In a growing former state teachers college which has just received University status. Enrollment 1,600. Experience preferred but not absolutely necessary. Need a person who is willing to accept responsibility. Must have MSLS or equivalent training and experience. 35 hours per week. 1 month vacation, state teacher retirement, and other benefits. Salary $\$ 7,500$ up depending on experience. Position open immediately. Send complete resume to Jerry $W$. Brownlee, Librarian, Julia Tutwiler Library, Livingston University, Livingston Al 35470.

\section{Readers Services}

PACIFIC NORTHWEST academic librarian seeks EXCHANGE agreement with a Reference Librarian located in/or between Boston and Washington, D.C. September 1969 to the ensuing February. Home institution must agree to forward salary of away librarian. Inquire prior to December 25, 1968. Box 742, CRL, 50 E. Huron St., Chicago 60611.

\section{Reference Services}

REFERENCE LIBRARIAN, preferably with science degree or strong background of experi-

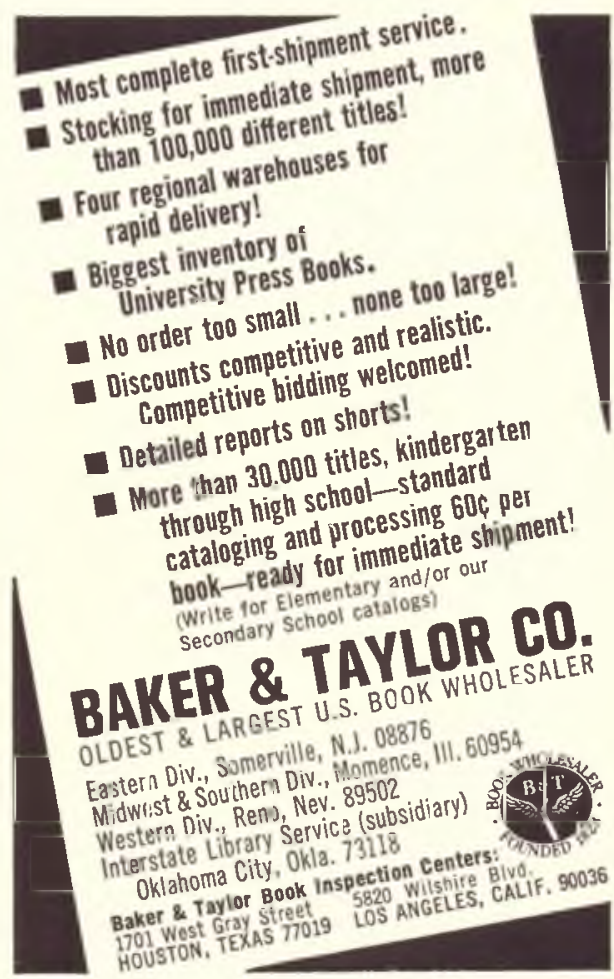


ence with the physical sciences, is required for expanding service to graduate and research interest. Keen interest in collection building and bibliographic work, including instructional work with students, is highly desirable. Salary will be commensurate with qualifications. Full faculty fringe benefits, plus the intangibles of life in British Columbia's capital city, a vacationer's mecca. Apply, with resume, to D. W. Halliwell, University Librarian, University of Victoria, Victoria, Canada.

ASSISTANT REFERENCE LIBRARIAN, Occidental College. Position now open. Duties include responsibility for special collections. Apply to: Tyrus G. Harmsen, College Librarian, 1600 Campus Road, Los Angeles, California 90041 .

REFERENCE-Circulation depts, head, University, with primary responsibility in reference. In heart of Green Mountain ski and Lake Champlain areas. Accredited MLS required, with adequate college-university reference experience. CATALOGING positions, accredited MLS, with minimum two years of experience: 2) cataloging of Vermontiana and rare books for the Special Collections Dept. Open now, with competitive salary dependent on qualifi1) serial and monograph original cataloging;

cations. Apply: Paul B. Kebabian, Director of Libraries, University of Vermont, Burlington, Vt. 05401. Phone (802) 864-4511, Ext. 651.

\section{Resources}

\section{ASSISTANT LIBRARIAN FOR RESOURCES} AND TECHNICAL SERVICES LIBRARIAN I: Salary range $\$ 7,164-\$ 7,908$ per annum. Duties: Assist in preorder and precatalog bibliographic searching, maintain out-of-print desiderata files, contact faculty in direct planning of library collections for curriculum support, assist in collaboration with circulation department in on-going inventory and collection building. For this position, some reading knowledge of foreign languages is necessary. (Russian especially desirable, though not necessary.) An active interest in the book trade and the application of computer techniques to the acquisitions process, combined with an aggressive personality, are especially important as qualifications for this position. Academic status. Annual leave, 24 working days. Liberal retirement plan, sick leave and health insurance plans. Write: Donald G. Wilson, Acting University Librarian, University of California Library, P.O. Box 5900, Riverside, California 92507. WE ARE AN EQUAL OP. PORTUNITY EMPLOYER.

Subject Specialists

\section{FOR THE RUSSIAN BOOK SECTION}

\section{Reference and}

\section{Source Material}

- Russian Literature: Classics, Contemporary

- Linguistics and Literary Criticism

- English-Russian and Russian-English Dictionaries

- Russian Language Records, Folk Songs and Dramatic Readings

- Children's Literature

- Books on Art

- Books on Science

- Textbooks on mathematics, geography, natural sciences, history, etc.

- Socio-Economic Literature

- Russian Atlases and Maps

- Soviet Magazines and Newspapers

Inquire about our out-of-print books and back issue magazines.

Write for Catalogs \& Prices

Phone 212 CH 2-4500

FOUR GONTIMENT BOOK GORP.
BIBLIOGRAPHER. New position, combining reference, cataloging, and some selection as specialist within functional organization. Academic status, good fringe benefits. Require graduate library degree and graduate study in Humanities or Social Sciences. Salary range $\$ 7,100-\$ 9,000$ depending on qualifications and experience. Box 738, CRL, 50 E. Huron St., Chicago 60611.

HEAD OF HUMANITIES DIVISION, Librarian III, $\$ 759-\$ 969$. 120,000 volume collection. Accredited degree, strong humanities background, minimum of three years college reference experience, administrative ability. 21 working days vacation, 12 days sick leave, good retirement program. Apply: C. J. Crisley, Chairman, Library Personnel Committee, San Diego State College, San Diego, California 92115.

LAW LIBRARIAN for joint appointment as faculty member and librarian. Both law and library degrees necessary. College of Law has faculty of 20 and student body of 450 , housed in new building with new library. Library of 93,000 volumes, staff of seven. Faculty status, TIAA/CREF, usual fringe benefits, salary open. An excellent opportunity for a strong person boxed in by circumstances or a head man who will never retire. An equal opportunity employer. For details, write Stuart Forth, Vice President and Director of Libraries, 207 Administration Building, University of Kentucky, Lexington, Kentucky 40506. 


\section{Now playing at leading college and research libraries worldwide}

The Literature Problem in

"PUTTING SCIENTIFIC INFOBMATION TO WORK"

a 36-minute film featuring a stellar cast: ASCA $^{\oplus}$ SCI $^{\oplus}$ PSI $^{\text {TM }}$ OATS $^{\oplus}$ IC $^{\oplus}$ CCCS ISI MAGNETIC TAPES CCLS CCPS ISI SEARCH SERVICE

The Institute for Scientific Information, the pioneering information people, wanted more college and research librarians to be aware of their services. A film seemed the most practical answer to accomplish this objective. By combining the talents of some ISI services with the exciting world of color, an interesting, informative, swiftly - paced film resulted. If your organization would like to screen this 36 minute, $16 \mathrm{~mm}$ sound and color film, attach the coupon below (or a copy of it) to your letterhead. No charge, of course, we'd like everyone to see the film.
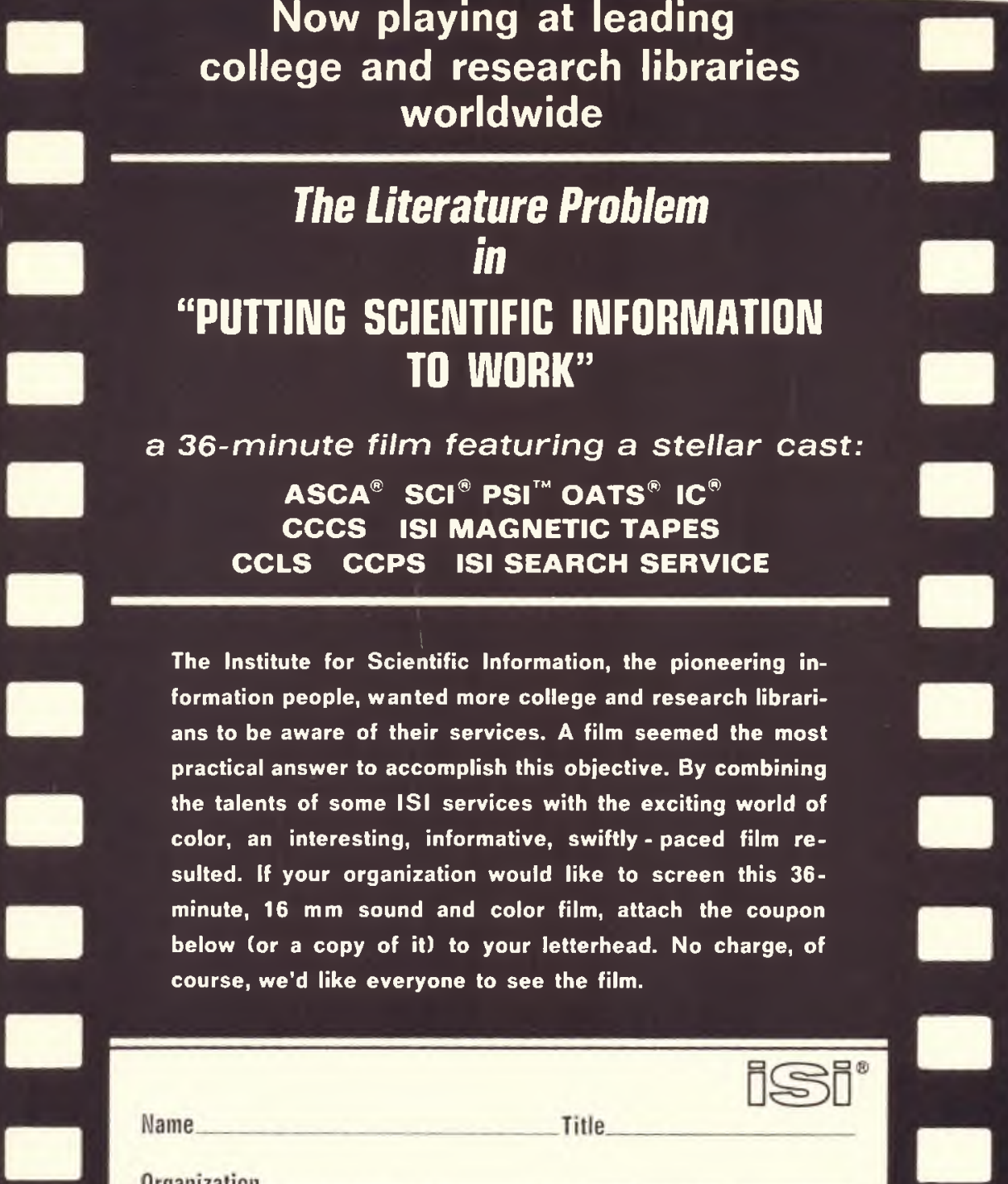

Name Title
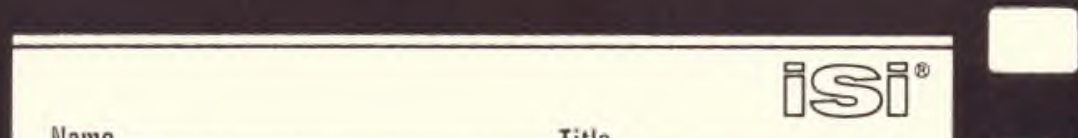

Organization

Library

Address

City.

State Zip

Country

IN UNITED STATES: send coupon to Depl. 12-119, Institute for Scientific Information, 325 Chestnut Street, Phila., Pa. 19106. IN EUROPE: contact Mr. Anthony Cawkell, 88 High Street, Uxbridge, Middlesex, England. Telephone Uxbridge 30085 or Mr. Peter Aborn, 6 Square Moncey, Paris 9, France. Telephone TRI 6738. IN JAPAN: contact Mr. Takashi Yamakawa, Tsutsumi Building, 13-12 1-chome, Shimbashi Minato-Ku, Tokyo. Telephone (591) 5181-6. 


\section{Library of Congress}

and

\author{
National Union Catalog \\ Author Lists, 1942-1962:
}

A Master Cumulation

\section{VOLUMES}

\section{OVER TWO MILLION ENTRIES}

$\$ 2888.00$

\section{Each Volume Billed on Delivery \\ $\$ 19.00$}

\section{WRITE}

\section{FOR DETAILED BROCHURE} AND ORDER FORM
With the announcement of its plans to begin immediate publication of a 152 -volume, one-alphabet cumulation of the four important supplements to A Catalog of Books Represented by Library of Congress Printed Cards, Gale has launched one of the major publishing events of 1969.

Gale's LC-NUC Author Lists, 1942-62, includes the entries in the following four supplements-

\section{Catalog of Books Represented by Library of Congress Printed Cards-Supplement [1942-1947]}

The Library of Congress Author Catalog. 1948-1952

The National Union Catalog: A Cumulative Author List, 1953-1957

The National Union Catalog: A Cumulative Author List, 1958.1962

Thus, the master cumulation is a one-stop source for quick, easy reference to bibliographical and cataloging data covering books, maps. atlases, periodicals, and other serials cataloged by the Library of Congress during the twenty-one years, 1942-1962, and by other North American libraries, 1956-62.

The format and type size of the entries now in the supplements will be retained in the cumulation, assuring the smooth continuation of any Polaroid or other photographic cataloging system now in use. Highquality printing and binding, plus the use of permanent/durable paper, will insure that the set withstands years of constant use.

Of course, a much larger and more inclusive cumulation, titled National Union Catalog Pre-1956 Imprints (and often called just "Mansell." after the publisher) is in early stages of publication. with completion expected in 1979, and libraries unable to afford both cumulations should give serious consideration to Mansell. Subscribers to the Gale cumulation will have in the meantime, however, not only the advantage of the immediate availability of this twenty-one-year bibliographical record but also the corollary gain of an immediate saving in the time and labor now being expended by catalogers, bibliographers, acquisitions personnel, scholars, and all other users of the present four separate LC-NUC author lists. In fact, the Gale cumulation should increase the productivity of library personnel and other researchers to a degree that its cost will be recovered many times before completion of Pre-1956 Imprints by Mansell in 1979.

Twelve or more volumes of the cumulation are scheduled for publication each month, with the entire 152-volume set scheduled for completion by the end of 1969. Production on the initial volumes is now well under way. Total cost of the set is $\$ 2888.00$ or a cost per volume of $\$ 19.00$.

Write us or call us collect if you want any additional information before placing your order or tentative reservation.

\section{GALE RESEARCH COMPANY}

Book Tower Detroit, Michigan 48226 1-3|3-96|-2242 